\title{
These children aren't creative: \\ Insights from beginning teachers on early childhood arts education
}

\author{
Susanne Garvis \\ Griffith University
}

\begin{abstract}
ACCORDING TO THE NATIONAL EDUCATION and the Arts Statement (MCETYA and Cultural Ministers' Council, 2007), all children should have access to high-quality arts experiences, especially within early childhood. The delivery of arts education in classrooms is dependent on early childhood teachers' beliefs (known as selfefficacy) about their own capability. This study explores the self-efficacy of beginning teachers as they engaged with the arts during practical experience in early childhood classrooms. Using Bandura's model of self-regulated learning, the study addresses issues of self-efficacy as a base for considering sources of an early childhood teacher's sense of agency related to teaching the arts. It starts to explain reasons for beginning early childhood teachers in another recent study reporting lower teacher self-efficacy for the arts (Garvis \& Pendergast, 2010). Findings suggest that practical experience in an early childhood classroom influenced the beginning teachers' beliefs towards teaching arts education. The findings highlight the need for training in the arts for beginning and supervising teachers.
\end{abstract}

\section{Introduction}

Arts education requires highly skilled teachers (Andrews, 2004). Pre-service teacher training helps beginning early childhood teachers to gain skills to enhance their confidence and capability in teaching the arts. When teachers feel more capable with skills, their personal beliefs about their own capabilities increase (Bandura, 1997).

In 2005, a National Review of Australian Music Education (DEST, 2005) raised a number of questions about the training teachers receive in music. The review highlighted a decline in the number of hours devoted to generalist primary pre-service education courses (DEST, 2005), suggesting pre-service teachers did not have adequate time to enhance their teaching skills in music.

In 2008, a 'Review of Visual Education' (visual arts), highlighted that most primary students received less than 40 minutes of visual arts education per week, while in some states one-quarter or more of respondent schools reported that visual arts education was not provided to all students in that school (Australian Government, 2008). The Review suggested that poor teacher education led to poor visual arts delivery in classrooms.

In a recent study of 201 beginning teachers in Queensland, Garvis (2010) found that many beginning teachers had low teacher self-efficacy for each of the arts compared to that for maths and English. Many of the beginning teachers suggested they did not have access to arts training during their teacher education or practical experience in a classroom.

Findings from these Australian studies highlight the absence of status and support for the arts in most initial teacher education programs, calling for improvement in pre-service teacher training and ongoing professional learning.

This study examines the impact of contextual features during practical experience on beginning early childhood teachers' self-efficacy and suggests how these may shape perceptions of confidence and competence. Building on previous findings of lower teacher selfefficacy for the arts among beginning early childhood teachers (Garvis \& Pendergast, 2011), this study provides information about 'why' teacher self-efficacy is low. In particular, the study looks at the influences of supervising teachers.

\section{Beliefs about young children and the arts}

There is a common belief that teachers should not interfere with young children's creative art. The belief suggests children are best left unhindered in their arts 
development. Richards (2007) challenges this view, arguing that learning in the arts is a social, cultural and historical act. In this view, early childhood professionals recognise the social and interactive nature of children's arts experiences. Pramling Samuelsson et al. (2009, p. 133) suggest children are creative and masters of play, but in order to become aware of distinctions, variation and invariance of the phenomena of the arts, children must be challenged by the teacher in order to clarify and develop their thought. The goal for early years teachers is to help children develop domainintrinsic knowledge about the arts, rather than merely using the arts as a means for developing art-extrinsic knowing (Pramling Samuelsson et al. (2009). For this to occur, early years teachers need to understand what is suitable domain-intrinsic knowledge in the early years and also how can this be developed with young children. As with other subject areas such as literacy and numeracy, early years teachers are also responsible for developing children's knowledge and skills in the arts.

\section{Theoretical connections}

Self-efficacy has a profound influence on personal endeavours and engagement within arts education (Garvis, 2010). A teacher's self-efficacy beliefs will determine the level to which the teacher will engage with arts in the classroom. Teacher self-efficacy for the arts is created through social influences and feedback, particularly from others deemed significant (Garvis, 2010). It develops over time and through personal and vicarious experiences (Bandura, 1986). Self-efficacy is responsible for the motivation and the actual amount of effort an individual will bring to the task of teaching the arts.

Bandura (1997) suggests that the higher the sense of self-efficacy, the greater the perseverance and the higher the chance of the pursued activity being performed successfully. Teachers with higher selfefficacy were likely to put more effort into planning and teaching, to have higher expectations, and to find strategies that would help students learn (Bandura, 1997). Moreover, beliefs appear to be influenced by confidence (Tosun, 2000), the level of content knowledge for a subject (Borko \& Putnam, 1995; Muijs \& Reynolds, 2001) and support (Ashton \& Webb, 1986).

According to Bandura (1997), there are four sources that create and influence teacher self-efficacy: mastery experiences, vicarious experience (modelling), verbal persuasion and emotional arousal. Mastery experience is considered the strongest source of efficacy (Bandura, 1997). When the performance in teaching arts education is perceived a success, self-efficacy is raised. When the performance in teaching arts education is perceived a failure, self-efficacy beliefs are lowered. The level of emotional arousal (either excitement or anxiety) adds to the feeling of mastering a task or feeling incompetent. Vicarious experiences are associated with the modelling of the task by another. When the observer can identify the skill with the modeller, the observer's self-efficacy is enhanced. It is important that teaching the arts is modelled for beginning teachers. The final source, verbal persuasion, may be a talk on the task being performed, as in feedback from a supervising teacher. The potency of verbal persuasion depends on the credibility, trustworthiness and expertise of the persuader (Bandura, 1997).

Teacher self-efficacy research within the arts has shown similar results. Previous research by Temmerman (1997) and Bartel and Cameron (2002) has shown that a perceived lack of competency to teach the specific knowledge and skills required in music was a significant internal factor affecting teachers' perceptions of their musical ability. Furthermore, in a comparison between New Zealand and Canadian generalist teacher selfefficacy towards music, levels of competence and selfefficacy clearly affected curriculum (Bartel, Cameron, Wiggins \& Wiggins, 2004), with few teachers able to show an understanding of students' musical thinking. Teachers were unable to make judgements 'about the value or importance of the consequences of an action' (Bartel et al., 2004, p. 88). These results suggest teacher self-efficacy has a strong influence on teaching the arts in early childhood classrooms.

\section{Focus of study}

This study focuses on beginning early childhood teachers' perceptions of their teacher education practical experiences in the arts and the impact of these experiences on their teacher self-efficacy.

\section{Method}

Twenty-one beginning early childhood teachers participated in the study. All were female, aged between 21 and 45+ years, and located throughout Queensland, Australia. Ethical approval was gained for this project, and convenience sampling was used to select participants. Respondents were contacted via advertisement of the project through professional teacher organisations (three early childhood organisations were contacted) and also emailing school administrations across Queensland. Out of 78 emails sent, 21 teachers responded (a response rate of 27\%). This convenience sampling method does not purport to produce findings that are generalisable across the entire population. However, it does provide an insight into a sample of early childhood educators that will be useful in developing further research in this area. 
The beginning early childhood teachers were recent graduates from a teacher education institution and within the first three years of their careers. They taught in private and public schools. The survey collected demographic information about them, and they were also asked to measure their level of teacher self-efficacy for the arts (using the Teachers' Sense of Efficacy Scale by Tschannen-Moran and Woolfolk Hoy, 2001) and to answer open-ended questions on their arts experiences while on practical experience. The Teachers' Sense of Efficacy Scale comprised 24 questions. Each question consisted of a nine-point Likert scale.

In the open-ended questions, participants were asked to list positive and negative experiences they could remember from their teacher training and classroom practice. During the latter, the pre-service teacher observes the supervising teacher and also begins to engage in teaching and planning the children's learning. In Queensland, for pre-service teachers to be eligible for teacher registration, they must spend at least 100 days in a classroom with a registered teacher.

Quantitative analysis was used to determine the current level of teacher self-efficacy of the participants. Results from this part of the study have already been published in the literature. English (6.81) and maths (6.81) produced the highest mean for teacher self-efficacy, followed by visual arts (4.86), music (4.39), dance (4.21) and drama (4.19). Media (3.98) had the lowest mean for teacher self-efficacy (Garvis \& Pendergast, 2011).

This paper reports on qualitative data from the survey, providing information about the contextual features that result in the low levels of teacher self-efficacy for the arts. Content analysis of the data showed key themes that were common across beginning early childhood teachers' perceptions of practical experience during teacher education. Content analysis was seen as 'a research technique for making replicable and valid inferences from texts to the context of their use' (Krippendorff, 2004, p. 18). Our study found three key factors to have influenced beginning early childhood teachers' self-efficacy for the arts: the supervising teacher's practice, the supervising teacher's feedback, and the profile of the arts in the early childhood classroom.

\section{Results}

\section{Demographics}

Respondents were located in city (43\%), suburban $(47 \%)$ and rural $(10 \%)$ settings. The range of teaching experience was from two years to 37 years as an early childhood teacher. Respondents taught in prepreparatory $(5 \%)$, preparatory (33\%), Year 1 (33\%), Year $2(14.5 \%)$ and Year $3(14.5 \%)$. They held various qualifications that enabled them to become registered early childhood teachers. Qualifications included a Bachelor of Education (Primary) degree (61\%), Graduate Diploma (Primary) (14\%), Bachelor of Education (Early Childhood) degree (10\%), Graduate Diploma of Early Childhood (10\%), and a Diploma of Teaching in Early Childhood (5\%).

\section{Three key themes}

Beginning early childhood teachers generally focused on negative experiences that had occurred during practical experience in teacher training. These experiences were shaped by either supervising teachers' practice (modelling) or supervising teachers' feedback (verbal persuasion). Beginning early childhood teachers also talked about the lower profile of arts as a subject in the early years classroom. Less time was devoted to the arts compared to other subject areas (contextual influences). Each key theme is discussed below.

\section{Supervising teacher practice}

Experiences described by beginning early childhood teachers showed a clear lack of arts understanding by supervising teachers. This suggests that supervising teachers did not model suitable arts education practice to their pre-service teacher.

One beginning early childhood teacher wrote of a negatived experience while at a kindergarten with her supervising teacher:

One of the saddest moments of my prac teaching was when I was studying my Grad Diploma and I was at a well-regarded C \& $K$ kindergarten. I was there for two weeks and basically the same activities were set out. I questioned the director as to why some children were not getting involved in the art activities and she told me that 'this lot are not very creative!' This went against all my beliefs about early childhood education and I felt very sorry for those children (Beginning Teacher, 16).

Another beginning teacher also commented on the lack of arts activities they actually saw while on practical experience:

I did little arts work on Prac. If I did it was Art and the activities were always related to the unit I was teaching at the time. Very restricted though (Beginning Teacher, 1).

Limited or no modelling of arts teaching appeared common (16 out of 21 teachers) among the beginning early childhood teachers who were surveyed:

I never saw it used on any teaching prac (Beginning Teacher, 4).

Many of my prac teachers did not do the arts (Beginning Teacher, 7). 


\section{Supervising teacher feedback}

Some beginning early childhood teachers wrote about negative comments from their supervising teacher regarding the teaching of arts education. They felt that the supervising teacher did not value the arts and made them constantly reassess the teaching of the arts within early childhood classrooms.

One beginning teacher wrote of a negative experience with a Year $1 / 2$ class. This beginning teacher was not happy with the way arts education was taught or framed within the school and did not appreciate the negative feedback about noise during her practical experience:

On my first prac at a public state school I was involved in art groups that consisted of all of things that I had avoided in my work in early childhood centres. Stencilled outlines of horses that children had to collage over, bubble blowing painting ... where was the freedom of expression in that? When doing a maths lesson in subtraction for a Year 1/2 class I sang 'Ten green bottles' with the class. The children sang along happily but my supervising teacher told me to keep the noise down so as not to disturb the children next door (Beginning Teacher, 15).

Another beginning early childhood teacher also spoke of the negativity from a supervising teacher when they tried to teach the arts themselves:

My teacher thought the arts weren't as important. When I started teaching them, I got in trouble (Beginning Teacher, 11).

\section{Subject profile}

Beginning early childhood teachers wrote about a constant struggle between the profile of arts and the profile of other subjects, such as literacy and numeracy, within schools. They suggested this had an impact on their current beliefs towards the arts and may have affected their future practice if a school was not dedicated to quality arts education.

One beginning teacher talked about the arts often being overlooked in schooling, with greater emphasis placed on literacy and numeracy. The teacher felt that, while literacy and numeracy were important, the arts in early childhood were just as important. Others suggested that some teachers de-intellectualised the arts, making it more of a 'fun' subject than an academic subject. Comments included:

This is a massive generalisation; however, I think that the arts, especially in the junior school setting but in middle/senior as well, tend to be overlooked in terms of importance (e.g. visual art is a 'fun' subject). While literacy and numeracy are of course extremely important I believe that the arts need to be given a bit more of a fair go. I think a lot of people often forget how important the tools that we learn and use in the arts classroom are, especially in relation to a great deal of tertiary study areas and eventually the workforce (Beginning Teacher, 10).

I do think it's disappointing that it doesn't get the chance to be more prominent in the classroom. These days behaviour problems are much worse than when I was in school and I think that, if these kids could use different arts to express themselves more, then maybe it would lessen the disruption a degree? (Beginning Teacher, 3).

Many teachers allow students to develop this 'bludge' mentality by not valuing the arts themselves. It is a difficult battle to reform students' opinions (Beginning Teacher, 8).

I don't think teachers that have been around a long time see the benefit of it or have the training or ability to implement it. They just teach reading, writing and maths (Beginning Teacher, 2).

What is clear from these comments is the negative profile of arts education in the early childhood classroom. Beginning teachers said they were aware of teachers having to make curriculum decisions about subject areas, and that other areas such as literacy and numeracy were given more time within the current educational agendas. While the majority of teachers suggested that the arts were important for children, they did not have time or the mastery experience to teach the arts. It is unknown if the supervising teachers understood the importance of developing domain-intrinsic knowledge about the arts. The beginning teachers suggested that the supervising teachers had stronger mastery experience of literacy and numeracy. These observations from early childhood beginning teachers were made during their practical experience, so it is unclear as to what extent their negative experiences may have impacted on their arts teaching practice.

\section{Final thoughts}

The above results provide an interesting starting point for analysis in the investigation of beginning early childhood teachers' perceptions of their preservice teacher education. Even though this study is limited by the small sample size of 21 participants, it provides a snapshot of beginning early years teachers. The findings provide an initial answer to 'why' they demonstrated lower teacher self-efficacy for the arts. It appears that practical experience with the arts during teacher training contributes to a teacher's self-efficacy. Without positive experiences created through the proposed sources of efficacy (mastery experience, vicarious experience, verbal persuasion, and emotional arousal), beginning early childhood teachers may feel they have little capability when teaching the arts in their 
own classroom. Long term, these experiences may contribute to lower teacher self-efficacy for the arts, creating a cyclical problem of failure for arts education in early childhood.

Teachers' educators are key players in helping provide positive sources of self-efficacy for the arts. It is important for them to help future teachers understand the power and richness of the arts. Based on the data collected, it is reasonable to believe that the supervising teachers had a strong impact on the future teaching practice of the beginning early childhood teachers.

The idea of 'teacher as learner' is important as a way forward for improving the teaching of arts education. If a supervising teacher's self-efficacy for the arts is low, how can they be expected to model and critique suitable arts practice in the classroom? Their lack of teaching in the arts will then affect the beginning teacher they are supervising. As Bandura (1997) suggests, giving teachers a sense of efficacy is critical if they are going to even attempt the task. We must look at supporting pre-service early childhood teachers and supervising teachers through ongoing professional arts learning.

Current practices in arts education courses within early childhood teacher education must be reviewed if teachers are expected to learn skills they can use in the classroom. Closer links must be made with supervising teachers. Arts experiences should be relevant to the needs of pre-service teachers, enabling them to develop the knowledge and skills to teach the arts within their early childhood classrooms.

More research is needed to help support the professional learning of arts education. Such research would provide teacher educators, schools and policymakers with evidence of crucial periods where beginning early childhood teachers require greater support. Successful professional arts learning programs could also be explored with supervising teachers.

\section{References}

Andrews, B. W. (2004). Curriculum renewal through policy development in arts education. Research Studies in Music Education, 23, 76-93.

Ashton, P. T., \& Webb, R. B. (1986). Making a difference: Teachers' sense of efficacy and student achievement. New York: Longman.

Australian Government (2008). National review of visual education. Retrieved 2 April, 2009, from www.dest.gov.au/... education/.../NRVE_Final_Report_pdf.htm.

Bandura, A. (1986). Social foundations of thought and action: A social cognitive theory. Englewood Cliffs, NJ: Prentice Hall.

Bandura, A. (1997). Self-efficacy: The exercise of control. New York: Freeman.

Bartel, L. R., \& Cameron, L. M. (2002). Self-efficacy in teachers teaching music. Proceedings of the Americal Educational Research Association Annual Conference, New Orleans.
Bartel, L., Cameron, L., Wiggins, J., \& Wiggins, R. (2004). Implications of generalist teachers' self-efficacy related to music. In P. M. Shand (Ed), Music education entering the 21st century (pp. 85-90). Nedlands, AU: International Society for Music Education.

Borko, H., \& Putnam, R. T. (1995). Expanding a teacher's knowledge base: A cognitive psychological perspective on professional development. In T. R. Guskey \& M. Huberman (Eds). Professional development in education: new paradigms and practices (pp. 35-65). New York: Teachers College Press.

Department of Education, Science and Training (DEST) (2005). National review of school music education: Augmenting the diminished. Perth: DEST \& Centre for Learning, Change and Development, Murdoch University.

Garvis, S. (2010). An investigation of beginning teacher selfefficacy for the arts in the middle years of schooling (Years 4-9). PhD Thesis. School of Music: University of Queensland.

Garvis, S., \& Pendergast, D. (2010). Supporting novice teachers of the arts. International Journal of Education and the Arts, 11(8). Retrieved 11 February, 2011, from http://www.ijea. org/v11n8.

Ministerial Council on Education, Training and Youth Affairs (MCETYA) (Federal) and Cultural Ministers' Council (2007). National statement on education and the arts. Canberra: Department of Communication, Information Technology and the Arts.

Krippendorff, K. (2004). Content analysis: An introduction to its methodology (2nd edn). Beverly Hills, CA: Sage.

Muijs, D., \& Reynolds, D. (2001). Teachers' beliefs and behaviours: What really matters. Journal of Classroom Interaction, 37, 3-15.

Pramling Samuelsson, I., Aspland Carlsson, M., Olsson, B., Pramling, N., \& Wallerstedt, C. (2009). The art of teaching children the arts: music, dance and poetry with children aged 2-8 years old. International Journal of Early Years Education, 17(2), 119-135.

Richards, R. (2007). Outdated relics on hallowed ground: Unearthing attitudes and beliefs about young children's art. Australian Journal of Early Childhood, 32(4). 22-30.

Temmerman, N. (1997). An investigation of undergraduate music education curriculum content in primary teacher education programmes in Australia. International Journal of Music Education, 30, 26-34.

Tosun, T. (2000). The beliefs of pre-service elementary teachers toward science and science teaching. School Science and Mathematics, 100, 374-379.

Tschannen-Moran, M., \& Woolfolk Hoy, A.W. (2001). Teacher efficacy: Capturing an elusive construct. Teaching and Teacher Education, 17(7), 783-805. 